\title{
Short term and seasonal forecast of hydro-power production by means of hydro-meteorological predictions
}

Hubert Holzmann

Ignacio Martin-Santos

Mathew Herrnegger

Hubert Holzmann, Ignacio Martin-Santos, Mathew Herrnegger

University of Natural Resources and Life Sciences Vienna

Austria

Corresponding author:

Hubert Holzmann, hubert.holzmannaboku.ac.at

https://doi.org/10.5592/CO/FTCE.2019.06 


\section{Short term and seasonal forecast of hydro-power production by means of hydro-meteorological predictions}

\section{Abstract}

The paper introduces the hydrological modelling activities of the Institute of Hydrology and Water Management at BOKU-University Vienna. A special emphasis is placed on the modelling potential for mean-term forecasts in hydropower production. The semidistributed hydrological model COSERO is briefly described and its application in the framework of the European research project Clim2Power is outlined. First preliminary results are promising, and it is expected that this kind of activities will enhance the potential for forecasting hydropower production and will thus gain future benefits for the strategic and economic planning of energy dispatchers.

Key words: hydro-power production, hydrological modelling, hydrological forecasts, ecosystem services, seasonal climate forecasts

\section{Primjeri hidrometeoroloških prognoza za kratkoročne i sezonske prognoze proizvodnje na hidroelektranama}

\section{Sažetak}

$\cup$ radu su predstavljene aktivnosti hidrološkog modeliranja Instituta za Hidrologiju i gospodarenje vodama na bečkom sveučilištu BOKU. Posebno je naglašen potencijal modela za srednjoročnu prognozu proizvodnje struje pomoću hidroelektrana. Semidistribuirani hidrološki model COSERO je ukratko predstavljen, kao i njegova primjena u okviru europskog istraživačkog projekta Clim2Power. Preliminarni rezultati su obećavajući: očekuje se njihov doprinos povećanju potencijala prognoze proizvodnje električne energije, čime se u budućnosti mogu ostvariti mjerljive koristi kroz strateško i ekonomsko planiranje distribucije energije.

Ključne riječi: proizvodnja električne energije pomoću hidroelektrana, hidrološko modeliranje, hidrološko predviđanje, usluge ekosustava, sezonske klimatske prognoze 


\section{Introduction}

The discharge and streamflow in rivers are hydrological variables describing different aspects related to water depths and flow conditions in streams. Consequently, many disciplines rely on the knowledge of runoff conditions. This includes activities related to flood management, hydropower production (HPP), structural river planning, ecosystem management, navigation and water resources management like water storage, drinking water supply, or irrigation.

Due to this importance of discharge data, a dense observation network has been developed in Europe and worldwide since many decades to support and enhance the understanding of runoff regime. Nevertheless, there are limitations in observations, which point to the need for making alternative assessments of runoff in ungauged basins, for extreme conditions, which have not been observed, or for future projections due to environmental changes. In this respect, hydrological models are useful instruments for transferring meteorological data - which are mostly obtainable - into runoff.These estimations subsequently provide information for decision making in the above mentioned branches. An important economic branch related to runoff is hydropower production.Also, due to limited energy resources, the planned transition from fossil fuel based energy to "clean" energy sources demand places emphasis on the importance of renewable energy sources (RES). Here photovoltaic, wind energy, and hydropower systems form the most important technologies in Europe and they already significantly contribute to the total energy production. The production and trading in electric energy is no longer a national activity, but takes place on an international level. For instance, on the European energy stock market, international energy dispatchers trade with energy from different national markets. Decisions on buying and selling energy is driven by economic boundary conditions like demand, market prices and availability of energy. In the context of hydropower, this requires proactive decision making by the players or stakeholders involved, taking into account future developments and expectations with regard to natural runoff formation, to water resources availability in reservoirs, and operational management decisions, and their impact on the power plant systems.

The time horizon for future perspectives ranges from a few days, to seasonal forecast, and to long-term projections. Short-term forecasts have been in place for many years now, and are implemented in short-term market models. This approach uses quantitative weather forecasts and the hydrological runoff response calculated by hydrological models. Long-term projections use climate change scenarios and support the energy sector in making their long-term decisions with respect to investments and adaptations in their energy portfolio. The mean-term and seasonal forecasts enable optimization of the storage and reservoir system. This latter approach will be described in more detail in this paper, as the authors are involved in the European research project Clim2Power, where the potentials of seasonal meteorological forecasts are implemented and tested in hydrological and economical models. The aims of the project, the consortium, and the first preliminary results, are described in Section 5. 


\section{Hydrological modelling at BOKU university}

\subsection{Historical demands in model applications}

As a part of the University of Natural Resources and Life Sciences Vienna (BOKU), the Institute of Water Management, Hydrology and Hydraulic Engineering (IWHW) plays a key role in the application and development of hydrological models. The first applications were developed in the late 1980s and they mainly dealt with the issue of flood protection and structural design of protection measures. In those days, standard open source software programs were also applied, such as the $\mathrm{HECl}$ rainfall runoff model from the US Corps of Engineers, a predecessor version of the current HEC-HMS model (see [I], [2]). Since the 1990s, there was an ongoing demand to use model forecasts for operational decision support in flood management and hydropower management. As these applications involved specific needs and designs with respect to space-time discretization, various process considerations, and data interfaces, the IWHW started to develop its own hydrological models, aimed at meeting requirements of specific customers. The first model concepts were strongly related to the well-known HBV (Hydrologiska Byråns Vattenbalansavdelning) model, developed in Sweden by Bergström [3], but was continuously adapted to user demands. Fist lumped model versions were expanded to (semi)distributed concepts and the IWHW model has gained growing acceptance as the so-called COSERO model, which stands for "COntinuous SEmidistributed RunOff" model (see [4], [5]). The COSERO model has been applied in numerous basins in Austria (e.g. Danube, Enns, Gail, Salzach, Traisen, etc.), as described in [6] - [10], but also in completely different hydro-climatic conditions in other basins worldwide (e.g. Zambezi, Niger, or basins in Southeast Asia) [ $\mathrm{II}$ ]. It is used for flood analysis and forecasting, water balance assessments, snow hydrological studies, and climate change impact assessments. As the model source code is available, it could be transferred and integrated both into decision support systems for flood warning (in the responsibility of the federal water management units) and in operational systems of hydropower companies (e.g. Austrian Verbund AG). Alternative approaches using dynamic modular hydrological model systems were developed and applied by [I2] and [I3].

In the framework of the aforementioned project Clim2Power [14] the hydrological model COSERO was applied for the Austrian-German Danube catchment, which forms a case study area in the project. In the following description of the model the case study domain is referred to in respective figures.

In 2018 the Institute of Water Management, Hydrology and Hydraulic Engineering (IWHW) split into two units, the Institute of Hydraulic Engineering and River Research (IWA) and the Institute for Hydrology and Water Management (HyWa), where the latter is still responsible for the hydrological modelling issues. 


\subsection{Model concept of COSERO}

The hydrological model COSERO is a semi-distributed, conceptual water balance model accounting for different hydrological sub-processes like snow accumulation and melt, glacier ice melting, interception, soil water storage, evapotranspiration, percolation, and surface and sub-surface runoff formation. Furthermore, routing processes along river branches are considered. The model input are time series of precipitation and air temperature; further meteorological variables can optionally be used for estimation of potential evaporation. The temporal resolution can be varied from hourly to daily or monthly, depending on the application demands. A schematic view of the COSERO model is shown in Figure I.

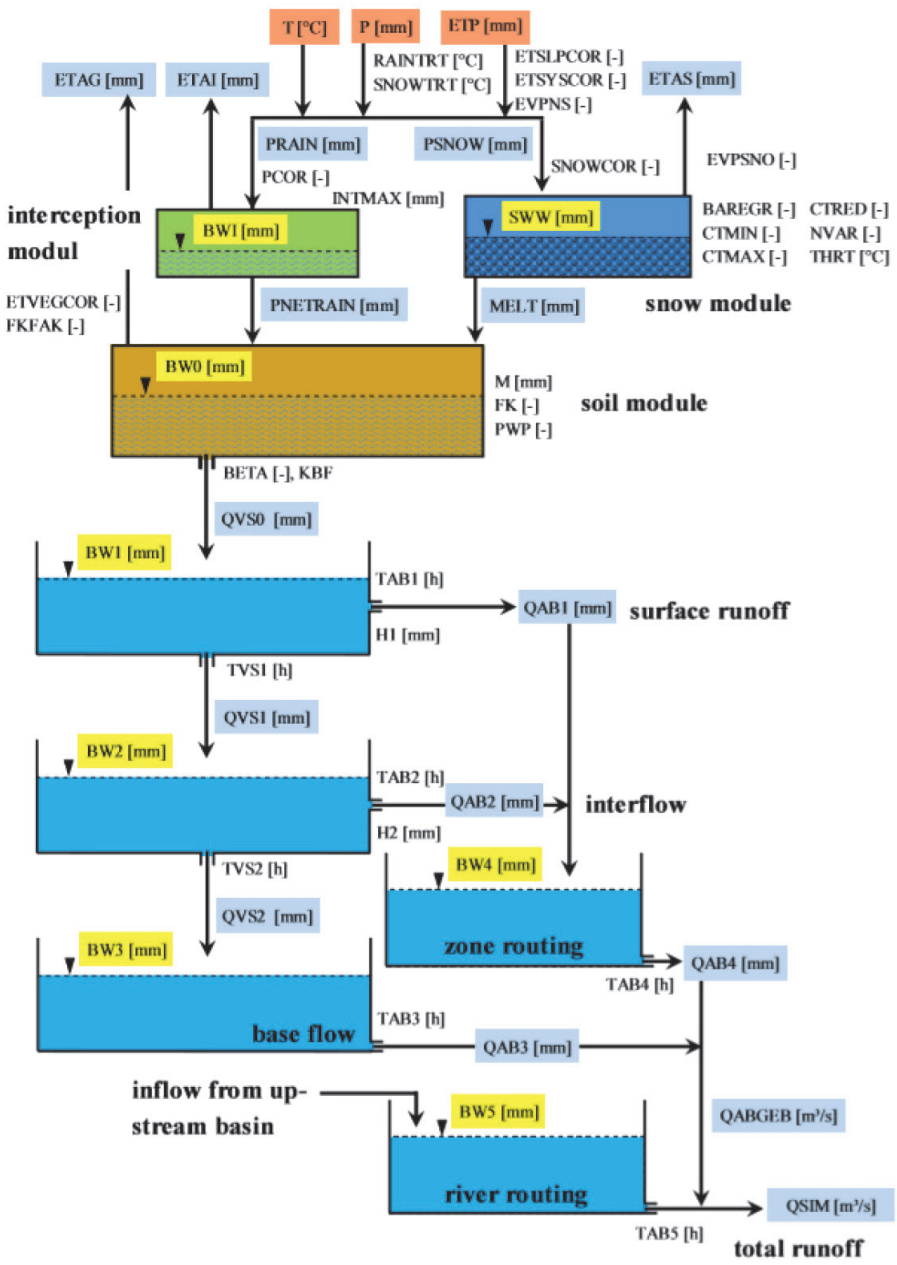

Figure I. COSERO model structure, including model parameters, system states and fluxes [see 15] 
The model uses different spatial modelling units for representation of the river catchment. The catchment can be divided into several "sub-basins" (see Figure 2). For the outlet of each subbasin, the model computes a simulated discharge. To account for physical heterogeneity within a subbasin, a further subdivision into hydrological response units (HRUs) is possible. Catchment (sub-catchment) boundaries, elevation zones, soil, and land cover information can be used as a basis for generation of HRUs. The zones are the basic spatial modelling units. Each zone has a set of parameters, receives an input, and simulates an output. Within the subbasin, the outflow of the zones is routed to the basin outlet and forms the subbasin runoff. This subbasin runoff is then routed downstream, incorporating simulated runoff of upstream basins when necessary. Sub-catchments are usually defined with respect to existing discharge gauges from the public observation network. In the case of the German-Austrian study domain used in the Clim2Power project, the catchment is divided into 65 subbasins and $3377 \mathrm{HRUs}$, with an area greater than or equal to five square kilometres. Once the model is set-up, the calibration and validation are necessary in order to gain stable parameter sets and to ensure that the model works properly in simulating runoff within the catchment. An example of the model performance for the sub-basin Inn, which represents an alpine catchment, is given in Figure 3.

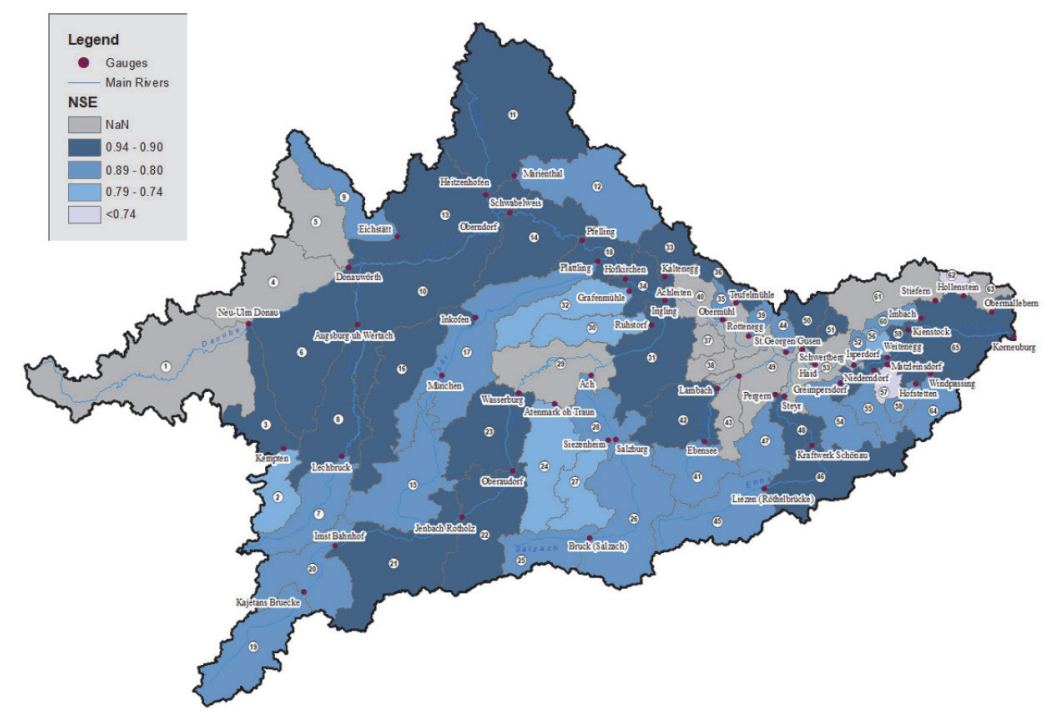

Figure 2. Spatial variety in model performance by Nash-Sutcliffe criteria

The precipitation input is formed of different data sets. High-resolution data from the Austrian and German weather services were used for calibration and validation purposes. Both SPARTACUS data for Austria and HYRAS data for Germany exhibit a high resolution of $\mathrm{I} \times \mathrm{I} \mathrm{km}$ and $5 \times 5 \mathrm{~km}$ grid, respectively. These data were aggregated to the areal level of respective HRUs. 
Model performance can be described for each observation gauge by applying some performance indicators. The spatial variation of the Nash-Sutcliffe criteria (see [16]), where values between 0.75 to 0.95 indicate very good performance, is shown in Figure 2.

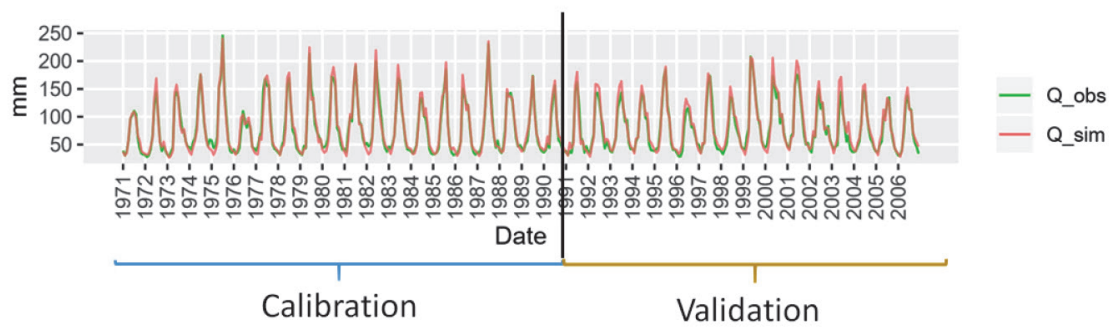

Figure 3. Model results of specific mean monthly discharge at Gauge Inn including calibration and validation

\section{Hydro-meteorological variables - data sources and products}

As described above, the minimum input required by the COSERO model is the precipitation and air temperature. As COSERO is a spatially distributed model, distributed input data are preferred to gain full advantage in describing spatial variability of processes. These data are aggregated for the model computation domain, which is the hydrological response unit HRU. This is done by means of pre-processing tools developed at the HYWA institute by applying and merging vector based delineation information (e.g. GIS shape files) and grid based data variables.

In Austria, the institution responsible for spatial meteorological data is the Central Bureau for Meteorology and Geodynamics (Zentralanstalt für Meteorologie und Geodynamik, ZAMG). Besides its activities in the synoptic weather prediction, ZAMG provides spatially distributed data sets including observed data and short term forecasts for the domain of the entire Austria (see [17]). The SPARTACUS gridded observational dataset describes spatial distribution of daily air temperature and precipitation sum over Austria. The variables include in particular the minimum and maximum air temperature, as well as precipitation depths at a spatial resolution of $|\times| \mathrm{km}$ and a temporal resolution of one day. The data have been available for the territory of Austria since the year 196I.

The INCA data constitute an even more advanced data set including variables such as precipitation, air temperature, relative humidity, radiation, and wind speed. Historic data are available from 2003; forecast data cover the range from nowcasting (up to 6 hours) to forecasts till 72 hours ahead. The spatial resolution is IxI km (INCA model) for the Austrian area with a 15-minute temporal resolution. For the spatial interpolation of e.g. rainfall, INCA not only uses point data at gauging sites but also applies elevation information and radar data to consider topographical effects and persistence in frontal movements. 
In Germany, the German Weather Service (Deutscher Wetterdienst DWD) provides meteorological data. HYRAS is the equivalent distributed data set, which could be used for model validation in the Bavarian/German part of the model domain. Data on precipitation, air temperature, radiation and wind speed are available on a daily basis with a high spatial resolution of $5 \times 5 \mathrm{~km} 2$ for the period from 195I to 2006 (see [l8]).

For seasonal forecast purposes, DWD uses model calculations stemming from regional climate models. These model types are nested in global models, applying the global based calculations as boundary conditions for the regional scale. The coarse spatial distribution of approximately $60 \mathrm{~km}$ of the global model can be improved by this dynamic downscaling procedure. This is the case for the regional product COSMO-REA6, which provides meteorological reanalysis data in the $6 \mathrm{~km}$ grid spacing. The DWD forecast system is called MPI-ESM-HR/German Climate Forecast System GCFS2.0. Its spatial resolution is also $6 \mathrm{~km}$, and it provides data 6 months ahead in the daily time resolution, and the data set is updated each month.

With respect to the use of these different data sets for hydrological modelling, differences in the model performance can be expected due to different spatial resolution of input data. The coarser spacing of the climate model products leads to poor representation of topographically driven processes. Therefore, the quality of the modelling results regarding runoff calculations decreases with an increase in grid spacing. It is also clear that the quality of forecasts decreases significantly, as the lead time increases.

\section{Hydropower production}

The hydropower production potential is directly related to the quantities of discharge. As the hydrological model COSERO calculates runoff at each sub-catchment outlet, the overall hydropower potential $P$ (in $\mathrm{KW}$ ) can be downscaled on the local level according to the following general equation:

$P=\eta \cdot g \cdot H \cdot Q$

where $g$ is the gravitational acceleration $\left(\mathrm{m} / \mathrm{s}^{2}\right), \eta$ is the overall efficiency including hydraulic structures and turbines, $H$ is the net hydraulic head (in $\mathrm{m}$ ), and $Q$ is the discharge (in $\mathrm{m}^{3} / \mathrm{s}$ ) at the hydropower plant.

As the local design values like design discharge and efficiency functions of each single hydropower plant are not always made public and are not known, some empirical relationships according to Figure 4 can be used. A triangular relation between the discharge and production capacity can be assumed for runoff-river HPPs, which accounts for the discharge dependent variation of the net hydraulic head and efficiency. For reservoir hydropower plants the design discharge can be assumed constant. Some limitations can be due to low storage content (see Figure 4 right). In addition, some storage characteristics like the volume - water head relations are required. 
Furthermore, operational rules regarding release and storage intervals are needed. In the past, mainly seasonal behaviour with storage during spring and summer and release during winter could be assumed, while nowadays market prices for energy are the most significant drivers for the operation.
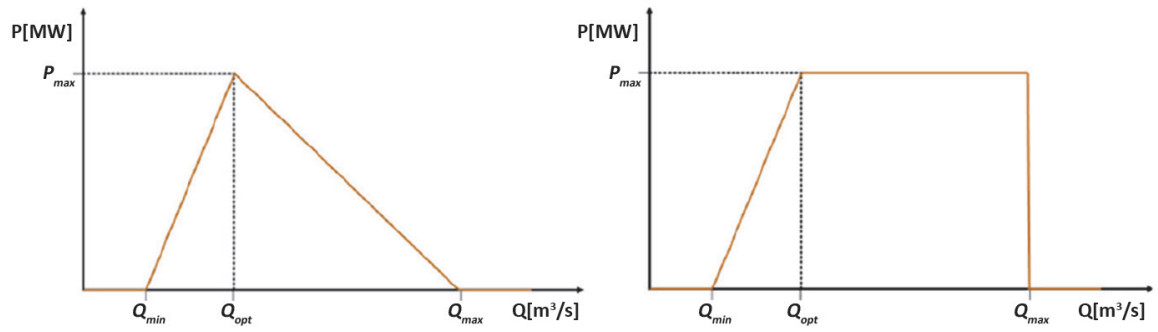

Figure 4. Relationship between capacity and runoff for runoff-river power plants (left) and reservoir power plants (right) used in the model (After [19])

In the current state of the project Clim2Power, the hydropower production was estimated on the regional level by means of statistical methods. The hydropower production was estimated by a non-linear regression relation to discharge. A comparison between the observed and calculated hydropower production is shown in Figure 5.The production data stem from the Austrian energy platform e-control. On the European level, some production data can be gained from ENTSO-E (European Network of Transmission System Operators for Electricity, see [20]).

If future development in the hydropower sector and its impact due to changing economic and environmental conditions should be assessed, statistical calculations as described above will no longer be sufficient. For this purpose, a HPP related concept will be established in the frame of the Clim2Power project. This means a full integration of each hydropower plant and its operational boundary conditions into the hydrological model system. This will enable consideration of changes in the regional and national power portfolio, in particular the change in demand driven operational rules, the change of runoff conditions due to climate change, or the construction and integration of new hydro-power plants.

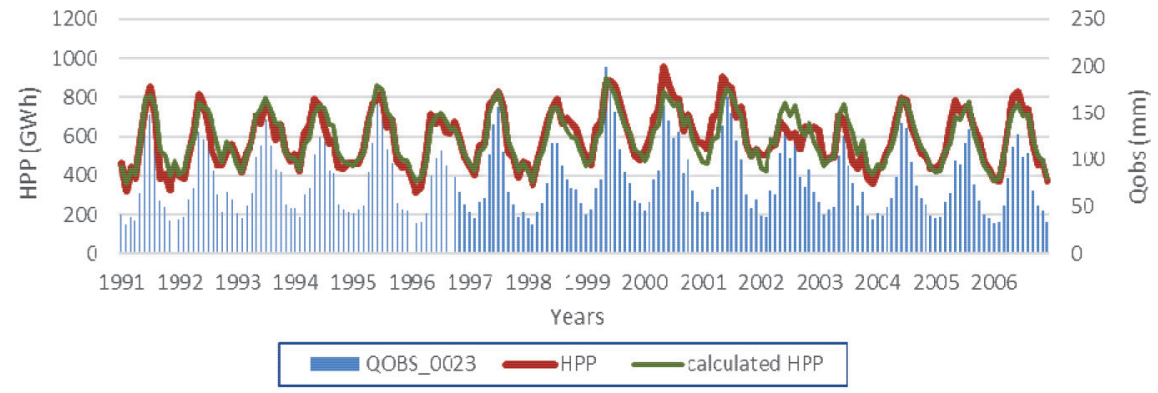

Figure 5. Statistical estimation of Hydropower production for the Inn River region 


\section{EU project Clim2Power}

\subsection{Project description}

The Clim2Power project aims to translate medium to long term evolution of climate into relevant indicators to support decision making in the energy system. The analysis covers the whole European power sector, complemented with four regional case studies, one of them being the German-Austrian case study region (Danube basin), to which the BOKU as partner of the project is committed.

The Institute for Hydrology and Water Management (HyWa) is responsible for the hydrology sector. This implies on the one side development of a hydrological model that is able to:

- estimate seasonal runoff in our region (as described in Section 2.2)

- translate it to potential hydropower production.

A short description of catchment characteristics, hydrological model setup, and first results obtained so far, are shown in the following sections.

\subsection{Study area}

The study area is the Upper Danube Basin upstream of Vienna, with Korneuburg as the outlet of the entire catchment. The boundary of our catchment represents the contributing area to the runoff of the Korneuburg gauge station. The size of the catchment is about $101502 \mathrm{~km}^{2}$, which corresponds to $12.7 \%$ of the entire Danube basin.

According to its structure, the catchment is formed of two distinct regions. The southern area is dominated by the Alps. As one moves to the north towards the Danube, low land valleys expand over large areas. For this reason, the main runoff contribution stems from southerly located tributaries of the Danube.

The hydrological regime is driven by the Alps region, characterized by low winter temperatures, snow accumulation, and melt processes. Reservoirs and dams are also relevant, as they are able to release or store considerable amount of water, which affects the runoff timing. 


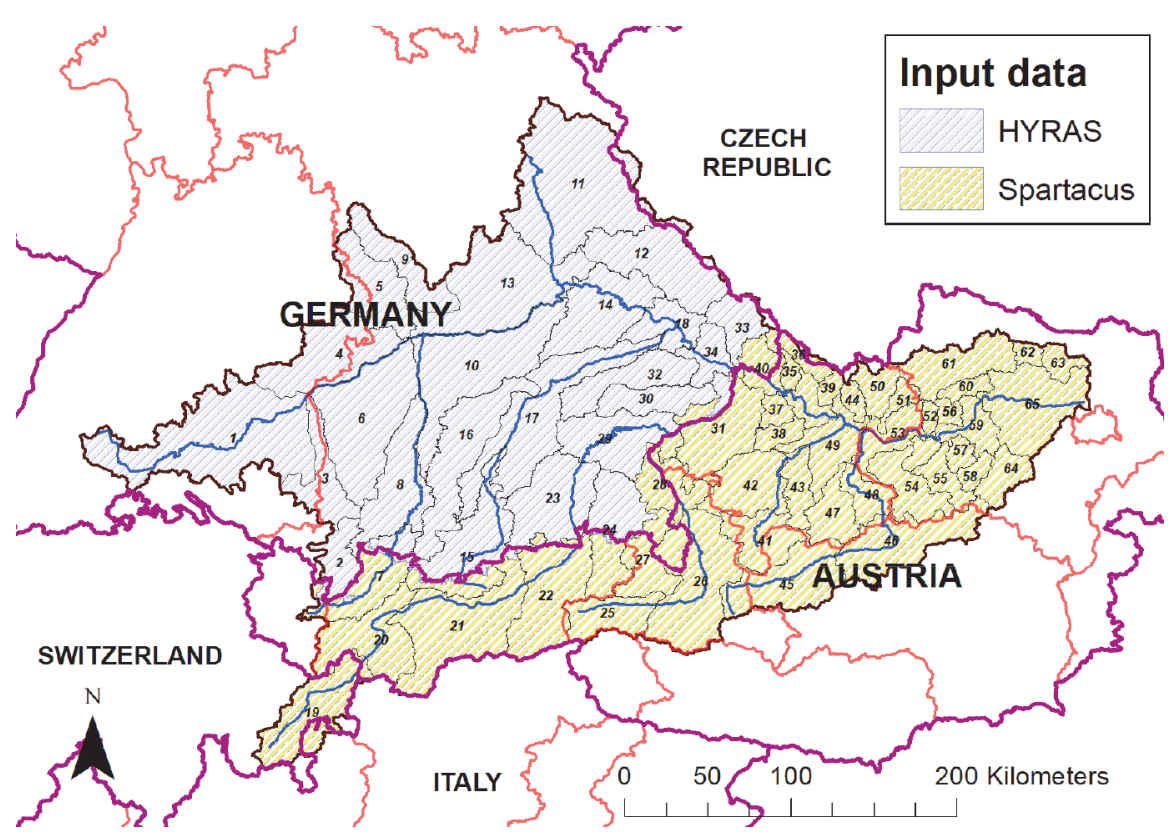

Figure 6. Model domain for Clim2Power project

\subsection{Preliminary results}

The aim of our group within Clim2Power is to provide a seasonal runoff forecast with our calibrated hydrological model, and later on to transform this information into hydro power production. First results have already been computed, as a preliminary test evaluation of our hydrological models and quality of the seasonal meteorological data.

The Input data to feed our model consists of a group of 10 ensembles (in the project's initial state) of seasonal forecast for precipitation and temperature. The seasonal meteorological data was in a first step provided in a coarse resolution of around 100 $\mathrm{km}$. Therefore, first test results are directly dependent on that fact. In following tests, new and better input seasonal forecast data are expected with enhanced ensemble numbers up to 50 and improved spatial resolution, since our DWD colleagues are working on a statistical downscaling procedure. An example of seasonal runoff forecasts for the spring and summer of 2019 is shown for the Danube at Vienna in Figure 7 below. The runoff forecasts are represented in such a way that green shaded areas represent the ensemble quantiles, while the green lines show the mean forecast. The red-dashed line represents the long-term mean of monthly runoff simulation for the period 200 I-20 I5. Runoff observations, when available, are depicted as black dots. Additionally, the historically observed runoff range (33.3-66.3\%) for the period 19962015 is shown in the dark boxes, including median as a black line. 
Likewise, a simplified transformation of runoff into hydropower production was carried out by means of the non-linear regression method as outlined above.
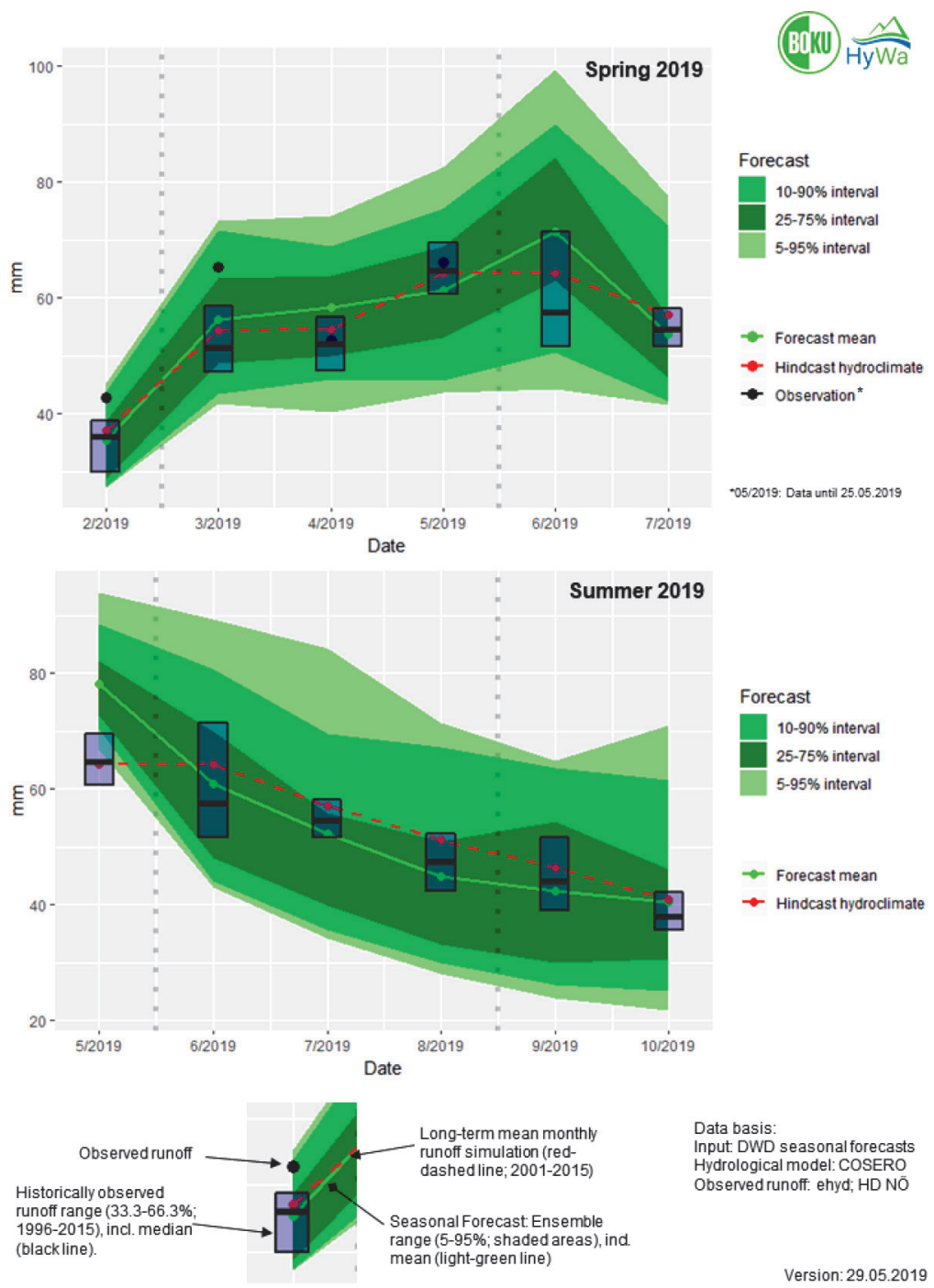

Figure 7. Seasonal runoff forecast for the Danube at Korneuburg

For this type of simulation, the input data are based on the real 6-month forecasts of meteorological parameters. The hydrological model applies these climate ensembles generating a set of runoff calculations, which can be described as confidence 
bands (see Figure 7). For the simulation conducted in the spring of 2019 some ex-ante analysis can already be made, indicating that the real observations for the 2 - and 3-month forecast interval are within the $50 \%$ confidence of the ensemble calculations. The I-month forecasts for March underestimated the real observation. The performance for the summer of 2019 run has still to be assessed in the following months. Generally, the results look promising and point to an improvement in the medium term forecasting.

\subsection{Related European research initiatives}

The Clim2Power project is closely aligned with other ongoing European projects. Two important European projects are led by the Copernicus Climate Change Service (C3S):

ECEM: European Climatic Energy Mixes (ECEM) aims to produce, in close collaboration with prospective users, a proof-of-concept climate service or demonstrator. The demonstrator allows the energy industry and policy makers to better understand and investigate the relationship between the climate and energy. The tool has both historical and projected data so that current energy systems can be assessed and future energy provision can be planned (see [2I]).

CLIM4ENERGY will bring together the complementary expertise of 7 climate research and service centres and II energy practitioners, acting as co-designers, to demonstrate, from case studies, the value chain from climate variables to actionenabling information in the energy sector. As proof of concept, it will deliver 9 energy-relevant Pan-European indicators of climate trends and variability with crosssectoral consistency, documentation and guidance, estimation of uncertainties, and demonstration of use (see [22]).

In summary, ECEM looks at the balance of demand and supply on different timescales and CLIM4ENERGY focuses more on the impact of weather related events on specific assets in a world characterised by warmer climate.

Recently launched European Projects include:

Plan4RES is a collaborative research and innovation project, which aims at developing an end-to-end planning tool to successfully increase the share of renewable energy into the European Energy System without compromising the system reliability. The project focuses on the European Electricity System, with its interactions with other energy factors, such as electricity, gas, heat, refrigeration, mobility (see [23]).

SECLI-FIRM aims at demonstrating how the use of improved climate forecasts, reaching un tp several months ahead, can add practical and economic value to decision-making processes and outcomes in both the energy and water sectors. The project will promote research advances in the most effective seasonal forecast for specific applications, as well as the uptake of seasonal forecast by industry, expanding the climate services market (see [24]).

S2S4E will offer an innovative service to improve RE variability management by developing new research methods exploring the frontiers of weather conditions for future weeks and months. The main output of S2S4E will be a user co-designed 
Decision SupportTool (DST) that for the first time integrates sub-seasonal to seasonal (S2S) climate predictions with RE production and electricity demand (see [25]).

\section{Conclusions}

The activities of HYWA-BOKU regarding hydrological modelling are briefly summarized in the paper, and an ongoing project initiative dealing with hydropower predictions on the European scale is described. It can be seen that the applied hydrological model COSERO has the potential to appropriately model the spatial distributed runoff within the Danube basin. The computed discharge can reliably be transformed to hydropower production estimates. The quality of the model results strongly depends on the data quality of meteorological variables, and will decrease with an increase in lead time. Good experience could be gained from the past for short term forecasts (few days ahead) whereas there are little applications so far for seasonal projections. The Clim2Power project merges these new developments in climate modelling with hydrological applications. First results seem to be promising as they reveal that some incremental benefit could be gained for seasonal runoff predictions and thus for the expected improvements in hydropower production. The expectations are not towards a detailed forecast of hydrographs, but trend and tendencies should be identified properly.

\section{Acknowledgements}

The authors thank the Austrian Research Promotion Agency (FFG) for supporting the Clim2Power project in the framework of the European research initiative ERA4CS.

\section{References}

[I] US Army Corpsof Engineers - Hydrologic Engineering Center: Hydrologic Modeling System HECHMS, Technical Reference Manual (2000).

[2] The Hydrologic Engineering Center (HEC): https://www.hec.usace.army.mil/; 2I-06-2019

[3] Bergström, S.:The HBV model. In: Singh,V.P. (Ed.), Computer Models of Watershed Hydrology, Water Resources Publications, Highland Ranch, CO, USA, pp. 443-476, 1995.

[4] Eder, G., Fuchs, M., Nachtnebel, H.P., et al.: Semi-distributed modelling of the monthly water balance in an alpine catchment, Hydrological Processes, 19 (2005), Pp. 2339-2360, https://doi.org/I0.1002/ hyp.5888

[5] Stanzel, P.. Kahl, B., Haberl, U., et al.: Continuous hydrological modelling in the context of real time flood forecasting in alpine Danube tributary catchments. IOP Conference Series: Earth and Environmental Science, 4 (2008), pp. 0 I2005, https://doi.org/ I0. I088/I 755-I307/4/I/0I 2005

[6] Herrnegger, M., Nachtnebel, H.P., Haiden, T.: Evapotranspiration in high alpine catchments - an important part of the water balance! Hydrology Research, 43 (20I2), pp. 460, https://doi.org/I0.2 I66/ nh.2012.132 
[7] Herrnegger, M., Nachtnebel, H.P., Schulz, K.: From runoff to rainfall: inverse rainfall-runoff modelling in a high temporal resolution. Hydrology and Earth System Science, 19 (2015), pp. 46 I9-4639, https:// doi.org/10.5194/hess-19-4619-2015

[8] Herrnegger, M., Senoner,T., Nachtnebel, H.P.:Adjustment of spatio-temporal precipitation patterns in a high Alpine environment. Journal of Hydrology, 556 (2018), pp. 913-921. https://doi.org/10.1016/j. jhydrol.2016.04.068

[9] Kling, H., Nachtnebel, H.P.: A method for the regional estimation of runoff separation parameters for hydrological modelling. Journal of Hydrology, 364 (2009), pp. 163-174, https://doi.org/ 10.1016/j. jhydrol.2008.10.015

[10] Wesemann, J., Herrnegger, M., Schulz, K.: Hydrological modelling in the anthroposphere: predicting local runoff in a heavily modified high-alpine catchment. Journal of Mountain Science, 15 (2018) 5, https://doi.org/ I0.1007/s I I629-017-4587-5.

[II] Kling, H., Stanzel, P,. Fuchs, M., et al.: Performance of the COSERO precipitation-runoff model under non-stationary conditions in basins with different climates. Hydrological Sciences Journal, 60 (20I5), Pp. 1374-1393.

[12] Holzmann, H., Massmann, C.: Development and test of a modular hydrological model concept with different degrees of complexity. Die Bodenkultur:Austrian journal of agricultural research, 64 (20I3) 3-4, pp. 47-52, ISSN 0006-547I

[13] Massmann, C., Wagener, T., Holzmann, H.: A new approach to visualizing time-varying sensitivity indices for environmental model diagnostics across evaluation time-scales. ENVIRON MODELL SOFTW, 5 I (2014), pp. 190-194.

[14] Clim2Power - Translating Climate Data into Power Plant Operational Guidance: https://clim2power. com/, 21-06-2019

[15] Wesemann, J., Holzmann, H., Schulz, K., Herrnegger, M.: Behandlung künstlicher Speicher und Überleitungen in der alpinen Niederschlags-Abfluss-Vorhersage (Dealing with artificial reservoirs and diversions in alpine rainfall-runoff forecasting). Österreichische Wasser- und Abfallwirtschaft, 2018, doi.org/I0.1007/s00506-018-050I-9

[16] Nash, J.E., Sutcliffe, J.V.: River flow forecasting through conceptual models, Part I: A discussion of principles, J. Hydrol., 10 (1970), pp. 282-290.

[17] Zentralanstalt für Meteorologie und Geodynamik, ZAMG: https://www.zamg.ac.at/cms/en/news; 2 I06-2019

[18] Rauthe, M., Steiner, H., Riediger, U., Mazurkiewicz, A., Gratzki, A.: A precipitation climatology covering Germany and neighbouring river basins - Part I: Gener-ation of a high-resolution gridded daily precipitation dataset (HYRAS) and first results - Meteorol, Z.22 (20I3), pp. 235-256, doi: I0.I | 27/094|-2948/2013/046.

[19] Koch, F., Prasch, M., Bach, H., Mauser, W., Appel, F., Weber, M.: How Will Hydroelectric Power Generation Develop under Climate Change Scenarios? A Case Study in the Upper Danube Basin. Energies, 4 (20I I), pp. I508-I54I; doi:I0.3390/en4 I0I508

[20] ENTSO-E, the European Network of Transmission System Operators for Electricity: https://www. entsoe.eu/ 21-06-2019

[2I] European Climatic Energy Mixes (ECEM); https://www.the-iea.org/projects/ecem/; 21-06-2019

[22] CLIM4ENERGY- Providing climate products for the energy sector; http://clim4energy.climate. copernicus.eu/; 21-06-2019 
[23] Plan4Res - Synergistic Approach of Multi-Energy Models for an European Optimal Energy System Management Tool, https://www.plan4res.eu/, 21-06-2019

[24] SECLI-FIRM - The added value of seasonal climate forecasting for integrated risk management, http:// www.secli-firm.eu/,21-06-2019

[25] S2S4E - Climate service for clean energy, https://www.s2s4e.eu/; 2I-06-20I9 